\title{
Elaborating Determinants of Location Strategy: A Case Study in Sulaymaniyah, Kurdistan Region of Iraq
}

\author{
Shram Shawkat \\ Tishk International University, Sulaymaniyah Campus, Iraq \\ Business and Management Department \\ shram@std.tiu.edu.iq \\ Cumhur Aydınlı \\ School of Information, Technology University of Cincinnati, Cincinnati, USA \\ cumhur_a@hotmail.com \\ Salim Demir \\ Independent Author \\ salimdemir43@gmail.com
}

DOI: $10.47299 /$ bsjmm.v1i2.58

\begin{abstract}
Many organizations acknowledge the importance of their geographical position and how it works as a key factor in driving the performance of a corporation. Yet a significant number of them fail in making efficient footprints that slows down their progress in the long-term. Making decisions on location strategy is thought as risky as it affects flexibility, labor availability, changes in costs, and tax regulations. In this respect, the current paper provides insight to discuss how location affects the effectiveness of a company. Based on the results, it was seen that location costs were the determinant which impacted the revenues of the GSM card sales significant at $P<0.01$. Secondly, traffic crowdedness, popularity of the location, crowdedness of the location, accessibility, and popularity of the neighbor shops were the other significant determinants which effected the shop GSM card revenues at $P<0.05$, respectively. Besides, it was observed that free parking, crowdedness of shop, and distance from the center are not the significant determinants of the revenues of the shops from the GSM card sales.
\end{abstract}

Keywords: Location strategy, customer, new business, Kurdistan, Iraq, long term success

\section{Introduction}

Many organizations acknowledge the importance of their geographical position and how it works as a key factor in driving the performance of a corporation. Yet a significant number of them fail in making efficient footprints that slows down their progress in the long-term. Making decisions on location strategy is thought as a risky move because it directly affects flexibility, labor availability, changes in costs, and tax regulations (Torlak et al., 2019). Thus, the best location being chosen by managers and business owners with consultation of an economic expert will prevent overproduction in one area and underproduction in another (Demir et al., 2019a). And when it comes to a corporate's business strategy and its external development, many different criteria are considered when they want to cover a new area of interest with their products (Demir at al., 2020; 2021).

A location strategy is the plan made by a corporation, organization, or a company to obtain a location by first determining their needs, requirements, and goals, then searching for a location that serves the 
company's needs the best (Demir et al., 2019b). The optimal goal of choosing best location strategy is to maximize their activity while minimizing their costs, taxes, and risks (MacCarthy \& Atthirawong, 2003). In order to make a location strategy many factors have to be taken into consideration including what type of space the corporation needs currently and in long-term, assessment of costs needed in different location, maximal transportation feasibility, how easy it will be for the company to get labor depending on its size in short term and long-term as well, how the community of the location respond to such companies, what are the governmental regulations in terms of taxes, what are the geopolitical risks the company may face in the future, what are the environmental regulations applied in the area and how compatible the company is with them (Budur et al., 2018; Rashid, 2018; Sahin, 2014)

Business strategies and plans followed by an institution will have direct impact on the performance and activity of a company (Budur \& Demir, 2019 a,b). These strategies have to serve both current position and long-term goals of the company including expectations and arrangement to how the company deals with obstacles faced in the future such as geographical resource decrease, market changes, political conflicts arising in the area, tax changes, and quality of life of their employees (Budur, 2018a; Mohemmed et al., 2020; Demir, 2020b; Torlak et al., 2021). Many companies make regional subdivisions in order to organize their work more efficiently in the form of a hierarchy with CEO getting reports back from managers of each subdivision (Budur et al., 2019; Zaim et al., 2020). The key factor in business strategy is measuring management performance of branches (Mohammed et al., 2020) and making new decisions based on these measurement, for example if a company's Branch $A$ earns $30 \%$ on its investment while Branch B earns only $15 \%$, then branch $A$ is twice as active than Branch $B$, therefore, consultations and negotiations have to be made in order to recognize factors that suppress growth of branch B and how to fix them (Talley-Seijn, 2004). Another importance of business strategy shows when one company's products have another competitor in the market. It becomes challenging for the company to win most customers; thus, they must make the best judgements in order to promote their products (Demir et al., 2020). Many companies lack business strategy in different locations, this has led to making big mistakes and losing their market (Ali et al., 2020; Poturak et al., 2020). A company in a new location must consider preference and culture of the people, and their desirability in different type of products, companies also have to bring in employees who already live in the location or area. These will bring the organization good reputation and trust of the people (Khan \& Yildiz, 2020).

Kurdistan Region of Iraq is a good place filled with many resources available to meet a company's needs in many different public and private sectors. However, finding an optimal location for a company can be hard and risky especially for foreign investors. One of the main factors that acts as a disadvantage for the Region is its conflicts with Baghdad, as well as its conflicts with terrorist groups from areas of central Iraq which make the Region un-reliable and the locations suitable for corporations risky. Another influential factor that affects location strategy is poor telecommunication resources and payments (Demir, 2019b). Many global companies have refused to open new branches in the regions because the region lacks technological advances that have shifted trading systems in the world (Demir et al., 2020). People still find it hard to buy their needs online, due to poor payment technologies and services (Rashid, 2018). However; the land is rich with many natural earth elements and resources, and the Region is determined to be at its developing stage, and it needs peak organizational activity to achieve its needs. For instance, the Region relies largely on manufacturers that work in the oil extraction fields, therefore makes a strategic location for these manufacturers. 
Another important advantage in choosing this region is low tax and large number of labors, which makes it a good location for construction companies.

It is important for business and economic researchers to focus on studying location strategy gap. The lack of research and knowledge on location strategies causes global investors to avoid making new factories and branches in the area. The government used to employ most of the working population, but lately due to the slow growth rate of the economy this method is not sustainable, and it is not working anymore, leaving many people jobless. (Talley-Seijn \& Margaret, 2004.) Therefore, the government has to make new strategies to employ methods of attracting international and local businessmen to work in the area in order to build the economy again (Amin \& Ahmed, 2020). After 2003, due to political stability and security investment and governmental efforts many new local businesses began to grow which can be counted as a huge step (Budur, 2018b; Kamal \& Shawkat, 2020). Therefore, any little effort made by localities and government will have major positive impact on the economy and more scientific research is needed in consideration of the current economic situation (Abdulla et el., 2020; Top et al., 2020).

In our research on GSM operators we asked people several questions in order to correlate location strategy with desirability, performance, and preference of each company including Korek Telecom, Asiacell, ZEIN, and others. We first included basic identifications like gender, nationality, income level, how much do they spend on credits per month, and whether they utilize internet services of their GSM operator. Then we included questions on the quality of their network, how well their GSM covers their area and how is their quality of calls. Next, we questioned their GSM operator internet quality including how they evaluate their coverage, how strong the internet signals are, and whether it stays un-interrupted or not. After that, we came to ask pricing structure whether they are reasonable for both credits and internet services and the overall value-added services. Then moving on to promotions we asked how people rate extra minutes and daily offers including overall promotions too. Then we asked people's contemplation if they wanted to switch their GSM operator, and their worry about including how informative they are on other operators, how much other operators charge for internet and credits, what other operators offer that can be better than their current, whether they lose accessibility to certain services and lastly if they think it will be easy for them to make sure everyone gets their new number. Then we asked about the corporate's image how stable their firms are, how innovative and forward looking they have been and their social contribution and whether this company is a firm leading Turkish GSM operator and their positive image. After that we asked an important question of the company's trust on a general level and on billing and cheating matters and whether they consider their customer's interests. Later we asked people to rate the conflict handling mechanisms and how cooperative they are making attempts to solve their problems. Finally, we asked about customer loyalty and satisfaction with their GSM operator whether they will use the line for longer or change it and how happy they are with their services and what they dislike and wished was different.

In conclusion, we realized that a company's location strategy and business strategy are in direct correlations with each other and they both affect their performance in their districts. Considering the many factors and criteria mentioned before will lead to choosing an ideal location, as well as changing location and opening new branches will do a corporation extra profit. They also have to make enough promotions and services for their customers in order to satisfy them and make their firm reliable and trustworthy. 


\section{Literature Review}

A location strategy is defined as the plan made by a corporation, organization, or a business to obtain a geographical location for an office or manufacturing place by first determining their needs, requirements. As we have mentioned before, it is perhaps very important for businesses to focus on their location and to have a specific strategy giving them good insight on where to perform their work. If we look at major companies and businesses around the world, we can see that they all focus on the same idea, and that is having a suitable place and location for their businesses. Many organizations acknowledge the importance of geographical position and how it works as a key factor in driving the performance of a corporation (Location Strategy, 2020). Yet a large number of them fail in making efficient footprints that slows down their progress in the long-term. The same is true for companies who require offices. In the city of Sulaymaniyah most major companies would want an office at Rand Gallery because it is the center of the city and closest to everywhere else. First, we will be looking at an article on bciglobal.com. The article is titled as "The Criteria for a successful location strategy" and it talks about how companies pick their locations. (Location Strategy, 2020.) At first, the article addresses the questions business owners ask when they think of location strategy, and they are the following:

- "Do we want to cover a region with one, two or more distribution centers or manufacturing plants?"

- "What is the right mix of onshore, nearshore and offshore locations for our back-office activities?"

- "Is it better to build a new plant in Asia and ship the products to Europe and the US and sell the products there or is a postponed manufacturing model the preferred option?"

Perhaps not all of these questions apply to us in the Kurdistan Region or even in many countries in the Middle East, but they could act as the ground for our questions that we formulate, such as whether we want one branch or more. Since Kurdistan region is an emerging market, according to researchers in the field, region attracts many new investigations, however businesses should focus on their performance triggers respectively (Budur \& Poturak, 2020; 2021; Mohammed et al., 2020; Zaim et al., 2020). In this respect, a good location strategy could be one of those triggers to impact customer favorable outcomes (Torlak et al., 2019; Demir et al., 2019). Further, it's proposed to have our headquarters to be in the city, to import our goods, or to rely on local goods, and many other questions could be added in this regard.

When it comes to the criteria used when picking the best location and having the best location strategy, the article further says, "Based on the business strategy and external factors different location scenarios can be defined and analyzed based on cost, qualitative and risk factors in order to determine to optimal location strategy going forward."

Therefore, when we look at the location options, we have in front of us, we have to see which location is cheaper for us. If I had the option between two very similar apartments and one was cheaper, I have to go for the cheaper one. Along with that, I have to look at the quality of my options, if a place is of better quality, then perhaps it is worth more money, you will then have to create a ratio to help you decide whether the price is too much for the quality or not. Most importantly, we need to consider the risk factors of our decision when we are trying to pick a location. For example, the price and quality might be really good, yet it is not a convenient location (Demir, 2020a). 
Another article by azcentral.com is titled "Why is Business Location Important?" and the title is very self-explanatory (Luthor, 2019). In the beginning briefing of the article, it talks about the importance of location and briefly mentions a few points that make a business location important. Amongst those points is to attract customers, to attract talent, but most importantly to establish themselves as a brand, and that will require a place that has enough space for self-branding where people can see your logo before entering your place and they can know you are there.

According to this article, research has shown that the location of a business plays one of the biggest roles when it comes to the success of the business. "The importance of the location strategy is especially important for these small businesses because it impacts whether enough profits will be generated to sustain the business" (Luthor, 2019). This is what the article says when talking about the importance of location strategies and thinks it is important for new businesses that hire up to nine people. This emphasizes further on the importance of location strategy when it comes to businesses. The article further points to the best example when it comes to businesses that need location strategy, restaurants. Restaurants indeed need the best location strategy because restaurants really depend on their locations to succeed, a restaurant without a parking area is very much useless.

The article later talks about the factors that should be taken into consideration when trying to pick a suitable location for your business.

\section{Demographics of the Location}

The first thing that they should look at should be to consider the demographics of the place. If the place does not have any need for that specific business, then it would be a waste of resources and money. Therefore, it is essential to consider the type of market that will be offered in that specific place and how suitable it is for the objectives of the company, otherwise business performance will regress due to this factor.

\section{Cost of the Location}

If there was indeed a need for that certain business in that certain location, then there might be other complications such as cost. While the place might be really busy with traffic and guarantee a good number of customers; the guarantee of customers might come at a cost which would be higher rent and which is true for many places in the city. Therefore, a company has to consider other factors such as their income in a year and take a deep look into considering the cost of the place in relevance to making profits.

\section{Other Factors}

Other factors would be the safety of the location, whether there is good parking space, good internet connection. These are all factors that could attract customers to the place.

Business owners need to find a perfect balance between all these factors and make sure they can get the better side of those conditions in order to improve business and financial performance, gain good recognition and reputation, as well as reinforcing their market position (Budur, 2018a).

What really important for companies to consider is to make sure that their companies are in safe places. And when I say safe places, I mean security wise, to avoid any kind of robbery or vandalism. The article later goes on into further details on how to solve each and every one of those problems specifically. 
The mentioned two articles above will serve as good ground for the claims we make in this research, because we can see that two different sources agree on the same concepts and methods in order to have a legitimate and proper location strategy and make sure you get the best location for your business. Furthermore, they state the importance of location strategy and give very good tips about certain things to look out for when trying to come up with a proper location for your business and tell you what to take into account and consideration.

Many other research and studies talk about the influence of location strategy on a business and the factors that should be considered in the process of making a good location decision such as Canel (1996) who provides business manager and owners the perfect step by step program for international facilities to solve their location strategy issues. Or when MacCarthy (2003) states that it can be a hard process for business owners to develop a location strategy that is suitable for the purpose of their corporation, he also mentions international location strategies and believes that international businesses should consider having offices or manufacturing sites in different countries. (MacCarthy \& Atthirawong, 2003). He identifies five major factors that are strong influencers on international location decision which are the total costs, their infrastructure, labor availability, economy, government, and political factors

\section{Methodology}

To further investigate the importance of the location parameters on the business performance of the GSM operator retail sellers, a survey questionnaire has been conducted. The questionnaire contained 12 questions which are mainly about "paid parking" , "free parking", "accessibility to the location", "crowdedness of location", "crowdedness of the shop", "traffic crowdedness", "distance from center", "location costs", "popularity of location", "popularity of the shop", and "popularity of neighbor shops". The questions were created by the researcher after discussing them with the experts of the field from various GSM operators in the region. Please see the appendix for the questions.

Those items were used as independent variable to measure their impact on the business performance. However, business performance of the shops was evaluated by "revenue" item which measured how much profit the concerning shop had in a particular time period from their GSM sales. The survey has been distributed among the owners of the shops. The owners have evaluated their locations from the points of aforementioned determinants. Secondly, they have evaluated their business performance by indicating exact amount of profit they had during a month on average. Besides, they have rated the determinants of the location by a metric over hundred point. They have given a rate from zero to hundred in which closer value to zero meant disadvantageous and closer to hundred meant advantageous for the shop.

There have been 118 shop owners who answered the questions and fulfilled the questionnaire. These data have been analyzed by SPSS program by using regression analysis technique. The aim of the questionnaire was to answer the question "what shall a manager of a shop do before select a shop location?" We have aimed to answer that question after analyzing the data appropriately. 


\section{Results of Hypotheses}

Regression analyses was proposed to understand the impact of each determinant on the revenue of the retail shops by selling GSM operator cards. To do this, we have used IBM SPSS 24 software.

Table 1 Impact of popularity of neighbor shops on the revenue of the shops

\begin{tabular}{|c|c|c|c|c|c|c|}
\hline \multicolumn{7}{|c|}{ Model Summary } \\
\hline \multirow[t]{3}{*}{ Model } & $\mathrm{R}$ & R Square & Adjusted & \multicolumn{3}{|c|}{ Std. Error of the Estimate } \\
\hline & & & \multicolumn{4}{|l|}{ R Square } \\
\hline & $.287^{a}$ & 0.082 & 0.07 & \multicolumn{3}{|c|}{26.61784} \\
\hline \multicolumn{7}{|c|}{ a. Predictors: (Constant), Popularity of Neighbor Shops } \\
\hline \multicolumn{7}{|c|}{ Coefficients $^{a}$} \\
\hline & & \multirow{2}{*}{\multicolumn{2}{|c|}{$\begin{array}{l}\text { Unstandardized } \\
\text { Coefficients }\end{array}$}} & \multirow{2}{*}{$\begin{array}{l}\text { Standardized } \\
\text { Coefficients }\end{array}$} & \multirow{4}{*}{$\mathrm{t}$} & \multirow{4}{*}{ Sig. } \\
\hline & & & & & & \\
\hline & & B & Std. & Beta & & \\
\hline & & & Error & & & \\
\hline \multirow[t]{2}{*}{ (Constant) } & & -7.250 & 13.66 & & - & 0.600 \\
\hline & & & & \multicolumn{3}{|c|}{0.531} \\
\hline Popularity of Neighbor Shops & & 0.304 & 0.192 & 0.287 & 1.986 & 0.039 \\
\hline
\end{tabular}

\section{a. Dependent Variable: Revenue}

Given in the Table 1, the impact of the popularity of the neighbor shops on the revenue was tested. It was aimed to understand whether the shops' revenues were increasing or decreasing when they are close to the popular shops around. The results revealed that popularity of the shops around explain 7 percent of the revenue of the shops. However, glancing on the indicator values of the regression analysis $(\beta=0.287, t=1.986, P=0.039)$, it was revealed that the impact is significant. Although the explained variance is not very high, still, it was suggested that closeness to the popular shops would increase the revenue of the GSM cars retailing shops.

Table 2 Impact of free parking on the revenue of the shops

\begin{tabular}{|c|c|c|c|c|c|c|c|}
\hline \multicolumn{8}{|c|}{ Model Summary } \\
\hline & \multirow{3}{*}{ Model } & $\mathrm{R}$ & R Square & \multirow{2}{*}{$\begin{array}{l}\text { Adjusted } \\
\text { R Square }\end{array}$} & \multicolumn{3}{|c|}{ Std. Error of the Estimate } \\
\hline & & & & & & & \\
\hline & & $0.054^{a}$ & 0.003 & 0.034 & \multicolumn{3}{|c|}{28.193976} \\
\hline \multicolumn{8}{|c|}{ a. Predictors: (Constant), Free Parking } \\
\hline \multicolumn{8}{|c|}{ Coefficients $^{a}$} \\
\hline \multirow{4}{*}{\multicolumn{2}{|c|}{ Model }} & & \multirow{2}{*}{\multicolumn{2}{|c|}{$\begin{array}{l}\text { Unstandardized } \\
\text { Coefficients }\end{array}$}} & Standardized & \multirow[t]{4}{*}{$\mathrm{t}$} & \multirow[t]{4}{*}{ Sig. } \\
\hline & & & & & Coefficients & & \\
\hline & & & B & Std. & Beta & & \\
\hline & & & & Error & & & \\
\hline & (Constant) & & 17.524 & 15.921 & & 1.101 & 0.281 \\
\hline \multirow{2}{*}{\multicolumn{2}{|c|}{ Free Parking }} & & -0.056 & 0.201 & -0.054 & - & 0.783 \\
\hline & & & & & \multicolumn{3}{|c|}{0.279} \\
\hline
\end{tabular}


Table 2 shows the results of regression analysis which tested the impact of free parking space on the shop revenue. Based on the results $(\beta=-0.054, t=-0.279, P=0.783$ ), it was observed that although there is a small variance explained on revenue by free parking space, this impact was not significant. As result, it can be said that there is no significant impact of free parking space on the shop revenues.

Table 3 Impact of accessibility on the shop revenue

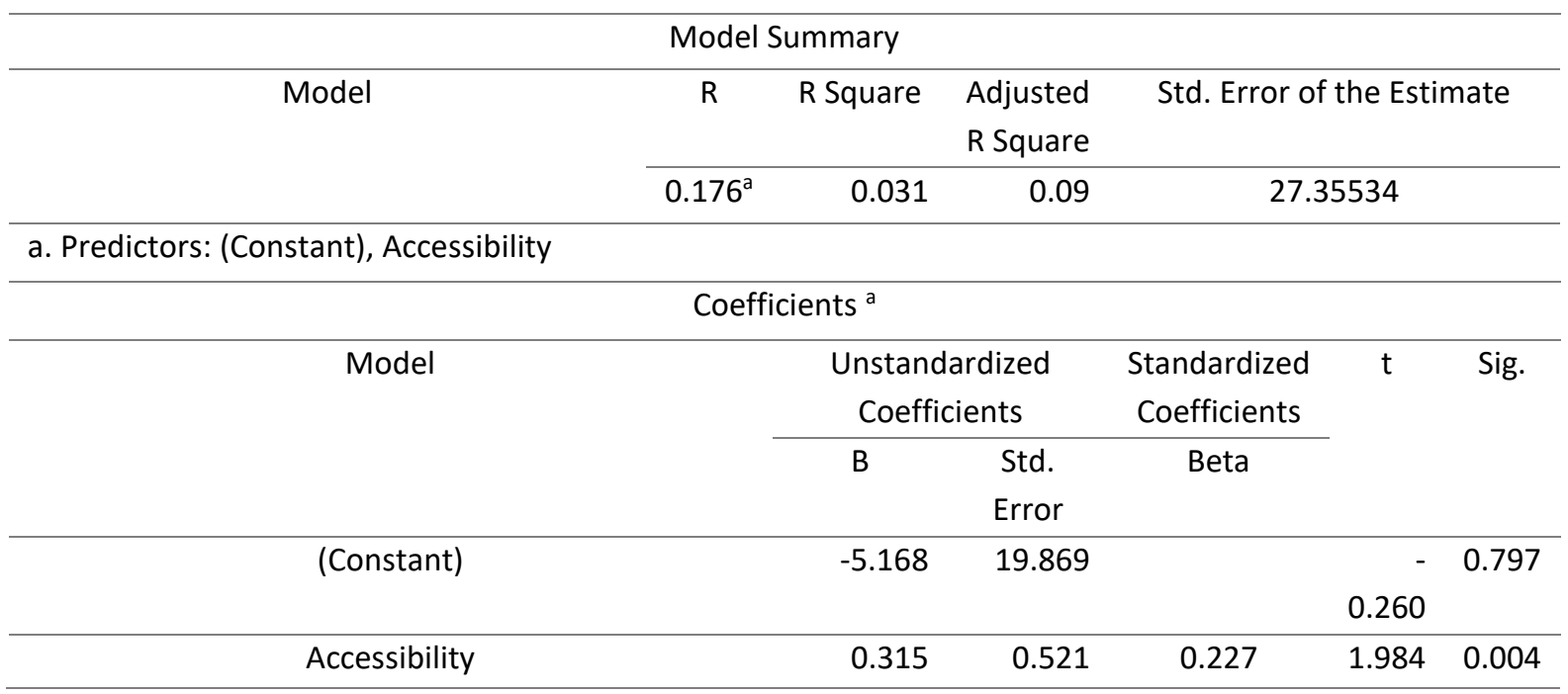

Table above shows the relationship between accessibility to the location and revenue. The results reveal that accessibility to the location significantly effects the monthly profit of the shops. Further, it was observed that accessibility explained $9 \%$ of the overall variance on the revenue of the shop. Based on the regression values of the model $(\beta=0.227, t=1.984, P=0.004)$, the impact of accessibility was accepted to be significant on the revenue of the shops.

Table 4 Impact of crowdedness of a location on the revenue of the shops

\begin{tabular}{|c|c|c|c|c|c|c|}
\hline \multicolumn{7}{|c|}{ Model Summary } \\
\hline \multirow[t]{3}{*}{ Model } & $\mathrm{R}$ & R Square & Adjusted R & \multicolumn{3}{|c|}{ Std. Error of the Estimate } \\
\hline & \multicolumn{6}{|c|}{ Square } \\
\hline & 0.301 & 0.091 & 0.12 & 26. & 95801 & \\
\hline \multicolumn{7}{|c|}{ a. Predictors: (Constant), Crowdedness of the location } \\
\hline \multicolumn{7}{|c|}{ Coefficients a } \\
\hline \multirow[t]{3}{*}{ Model } & & \multirow{2}{*}{\multicolumn{2}{|c|}{$\begin{array}{l}\text { Unstandardized } \\
\text { Coefficients }\end{array}$}} & \multirow{3}{*}{$\begin{array}{c}\text { Standardized } \\
\text { Coefficients }\end{array}$} & \multirow[t]{3}{*}{$\mathrm{t}$} & \multirow[t]{3}{*}{ Sig. } \\
\hline & & & & & & \\
\hline & & B & Std. Error & & & \\
\hline \multicolumn{2}{|l|}{ (Constant) } & -4.246 & 11.39 & & -0.373 & 0.712 \\
\hline \multicolumn{2}{|c|}{ crowdedness of the location } & 0.285 & 0.17 & 0.301 & 1.973 & 0.035 \\
\hline
\end{tabular}

a. Dependent Variable: Revenue

Next analysis was testing the impact of how crowded a location is on the revenues from GSM card sales. Table 4 shows the results of the analysis. Based on those results, it was observed that crowdedness of a location explained the variance on the revenue as $12 \%$. However, given in the results of the regression analysis, it was observed that crowdedness of location had significant impact ( $\beta=$ $0.301, t=1.973, \mathrm{P}=0.035)$ on the revenues of the shops. Hence, it can be concluded that the relationship is significant. 
Table 5 Impact of crowdedness of a shop on the revenue of them

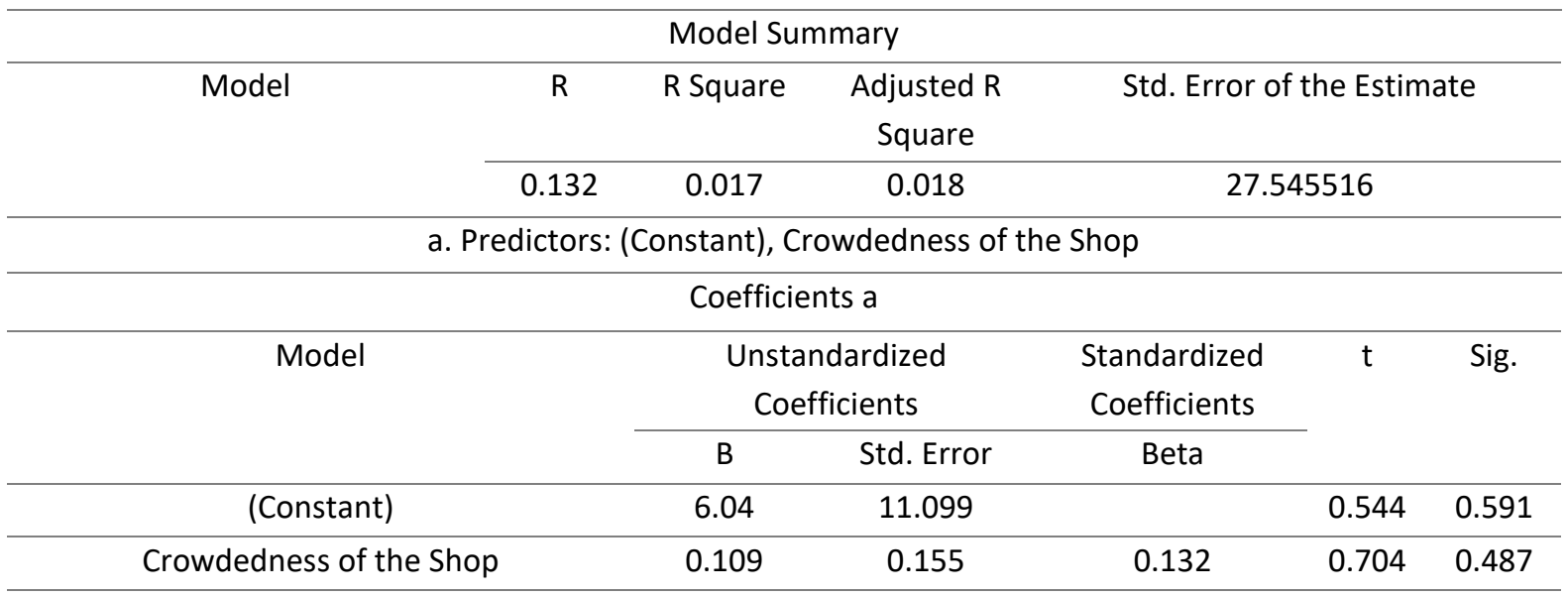

a. Dependent Variable: Revenue

After the crowdedness of a location, the impact of crowdedness of shop on the revenue was tested. It was aimed to understand whether there were any relations between how crowded a shop at a particular time during a day and revenue of that shop from the GSM card sales. The results given in the Table 5 shows that the impact of how crowded a shop doesn't have a significant impact $(\beta=0.132$, $t=0.704, P=0.487$ ) on the revenue.

Table 6 Impact of traffic crowdedness on the shop revenue

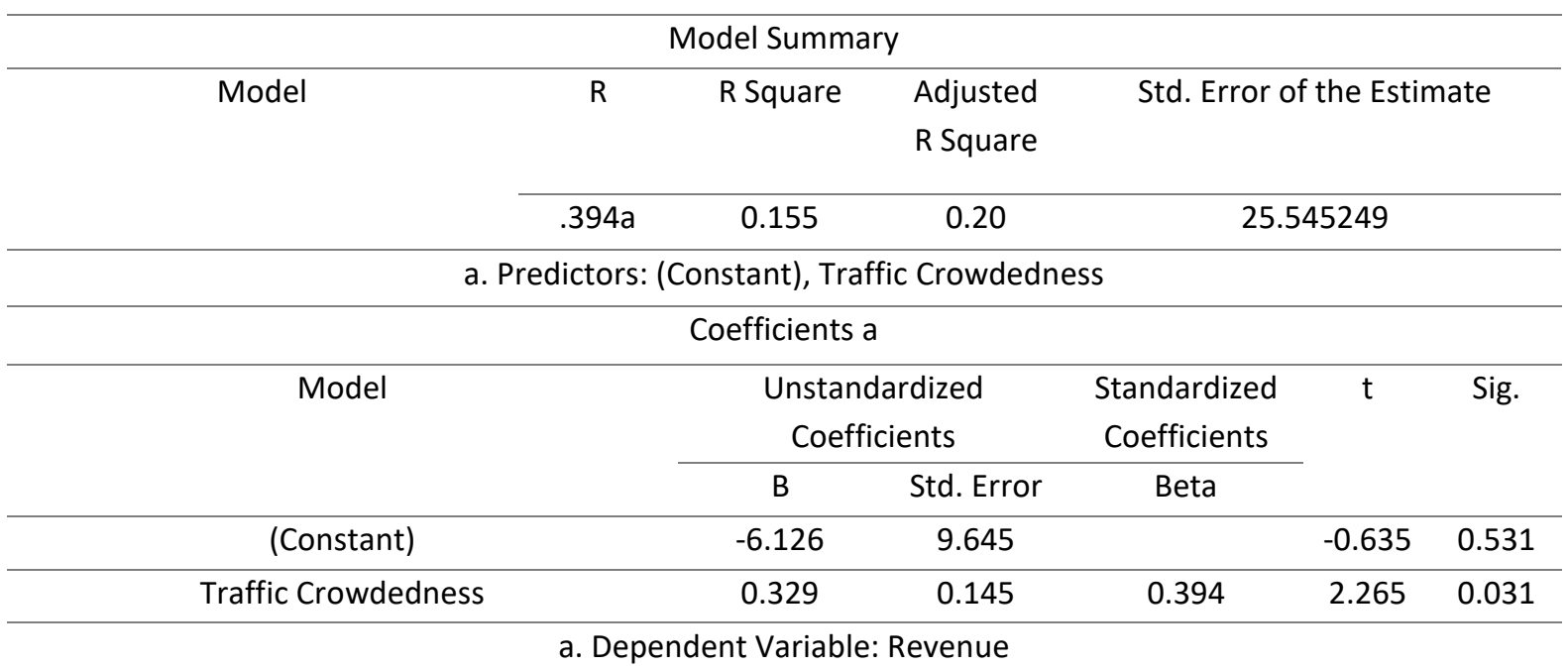

Given in the Table 6, we have tested the impact of how crowded the traffic at the concerning location on the revenue of a shop from the GSM card sales. Initial results have revealed that how crowded the traffic at the concerning location explains the revenue GSM card sales $20 \%$. Deeper investigations showed that the impact of the traffic crowdedness on the revenue $(\beta=0.394, t=2.265, P=0.031)$ was positive and significant. Based on these results, it can be suggested that if a shop selected from the location where the traffic load is heavy, GSM card sales would increase. 
Table 7 Impact of distance from the center on the revenue

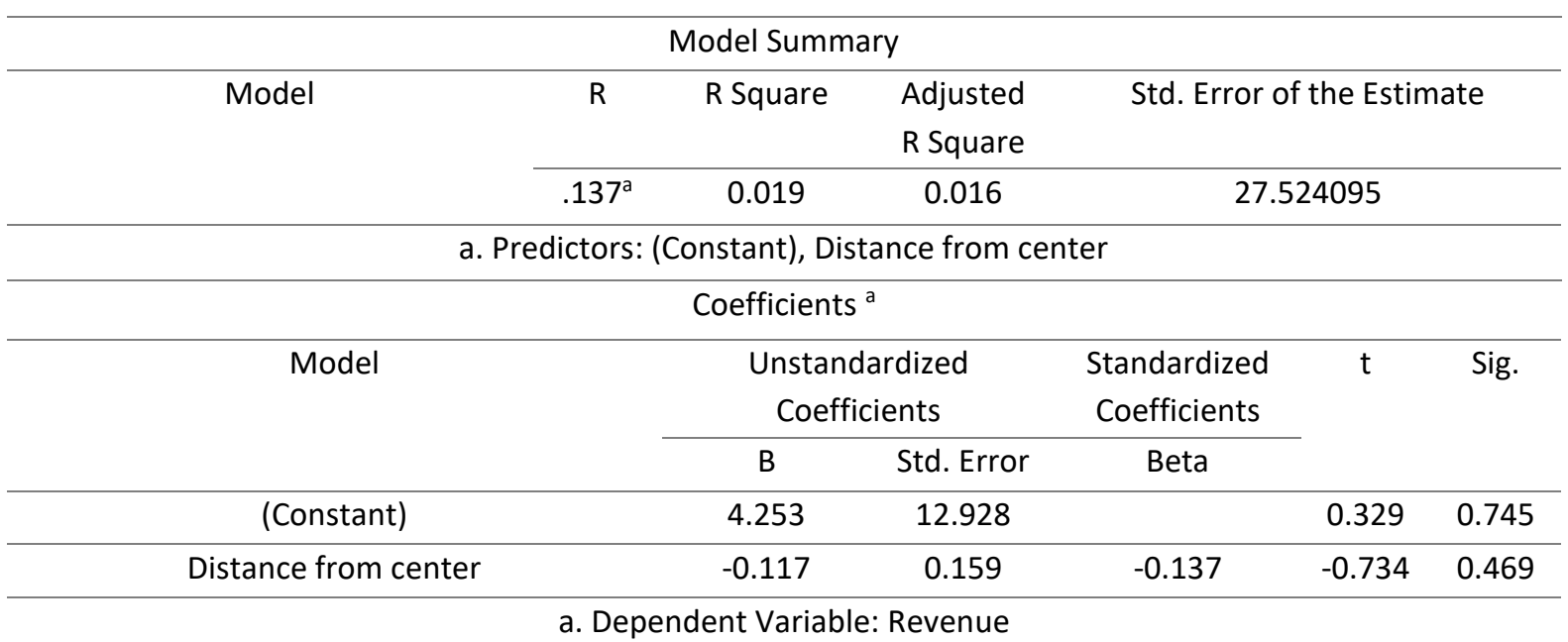

Table 7 elaborates the effect of distance from the center on the shop revenues from the GSM card sales. Center of a location or region is generally one of the most crowded places. Most of the citizens are having things to do in the center of the city every day. Hence, it was thought that distance from the center would impact the GSM card sales negatively. Besides, the observed results of regression analysis show that the impact of distance from the center on the shop revenue is not significant. The result means that how far the shop from the center doesn't play an important role on the GSM card sales.

Table 8 Impact of popularity of a location on the revenue

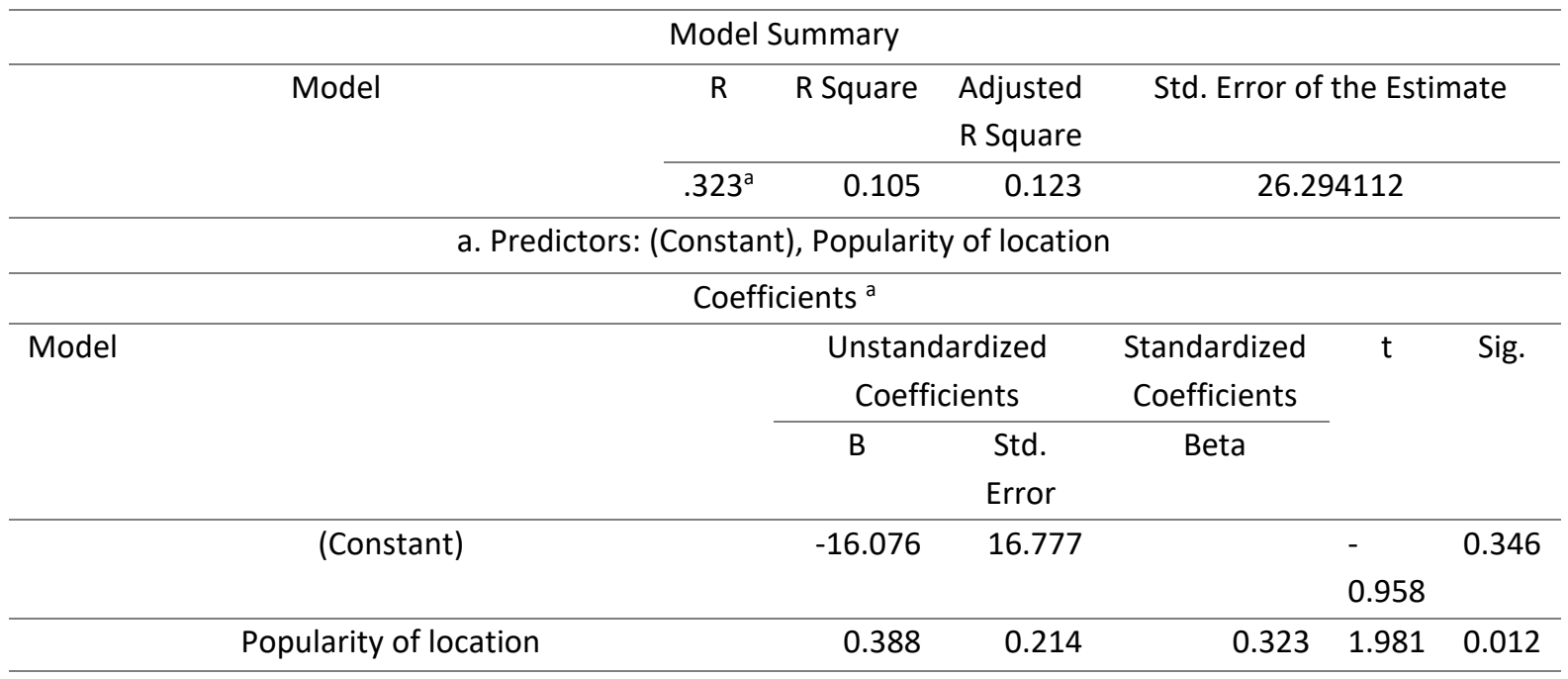

a. Dependent Variable: Revenue

Another regression analysis was conducted to test the impact of how popular a location on the revenue of a shop from the GSM card sales. The results have shown that popularity of a location explained $12 \%$ of the revenue of a shop from the GSM card sales. Further, the results of regression analysis showed that the impact of popularity of a location $(\beta=0.323, t=1.981, P=0.012)$ had significant impact on the shop revenue. It shows that a shop, which is located at the most popular location of a region would boost the revenue comparing to the shop which is in the least popular location. 
Table 9 Impact of location costs on the shop revenue

\begin{tabular}{|c|c|c|c|c|c|c|}
\hline \multicolumn{7}{|c|}{ Model Summary } \\
\hline \multirow[t]{3}{*}{ Model } & \multirow[t]{2}{*}{$\mathrm{R}$} & $\mathrm{R}$ & Adjusted & \multicolumn{3}{|c|}{ Std. Error of the Estimate } \\
\hline & & Square & R Square & & & \\
\hline & $0.555^{\mathrm{a}}$ & 0.308 & 0.381 & 23.8 & 7533 & \\
\hline \multicolumn{7}{|c|}{ a. Predictors: (Constant), Location costs } \\
\hline \multicolumn{7}{|c|}{ Coefficients $^{a}$} \\
\hline \multirow[t]{4}{*}{ Model } & & \multirow{2}{*}{\multicolumn{2}{|c|}{$\begin{array}{l}\text { Unstandardized } \\
\text { Coefficients }\end{array}$}} & Standardized & $\mathrm{t}$ & Sig. \\
\hline & & & & Coefficients & & \\
\hline & & B & Std. & Beta & & \\
\hline & & & Error & & & \\
\hline (Constant) & & -12.169 & 8.635 & & -1.409 & 0.171 \\
\hline Location costs & & 0.556 & 0.164 & 0.555 & 3.399 & 0.002 \\
\hline
\end{tabular}

a. Dependent Variable: Revenue

There are some locations where the costs are higher comparing to the rest of the locations in the region. Those costs might be mainly, rent, transportation, maintenance...etc. generally main reason behind this is the location is valuable. In this context, we tested the impact of location costs on the shop revenues from the GSM card sales. Given in the Table 9, results reveal that location costs explain the revenue from the GSM card sales $38 \%$. This percentage was the highest of all rest determinants. However, when the coefficient values of the impact were investigated $(\beta=0.555, t=3.399, P=0.002)$, it was observed that the impact of location costs on the revenue was highly significant. The results suggest that when the location costs are increasing, the revenues are also increasing rationally. By another meaning, costly locations contribute to the sales of shops positively.

Table 10 Summary of the regression analysis

\begin{tabular}{clccc}
\hline & & Adjusted R Square & Coefficient Value & \multicolumn{2}{c}{ Significant } \\
\hline 1. & Location costs & 0.38 & $0.555^{* * *}$ & Yes \\
\hline 2. & Traffic Crowdedness & 0.20 & $0.394^{* *}$ & Yes \\
\hline 3. & Popularity of the location & 0.12 & $0.323^{* *}$ & Yes \\
\hline 4. & Crowdedness of location & 0.12 & $0.301^{* *}$ & Yes \\
\hline 5. & Accessibility & 0.09 & $0.227^{* *}$ & Yes \\
\hline 6. & Popularity of Neighbor Shops & 0.07 & $0.287^{*}$ & Yes \\
\hline 7. & Free Parking & 0.03 & $-0.279^{\mathrm{P}>0.05}$ & No \\
\hline 8. & Crowdedness of shop & 0.02 & $0.132^{\mathrm{P}>0.05}$ & No \\
\hline 9. & Distance from the center & 0.02 & $-0.137^{\mathrm{P}>0.05}$ & No \\
\hline
\end{tabular}

Table 10 shows the summary of the regression analysis. The results were summarized based on the rank of the values starting from the biggest value to the smallest one. Based on the rank, it can be observed that location costs were the determinant which impacted the revenues of the GSM card sales significant at $\mathrm{P}<0.01$. Secondly, traffic crowdedness, popularity of the location, crowdedness of the location, accessibility, and popularity of the neighbor shops were the other significant determinants which effected the shop GSM card revenues at $\mathrm{P}<0.05$, respectively. Besides, it was observed that free parking, crowdedness of shop, and distance from the center are not the significant determinants of the revenues of the shops from the GSM card sales. 


\section{Conclusion}

The aim of the current study was to understand the impact of location selection on the business performance of the shops which are selling the various GSM cards in Kurdistan Region of Iraq. In order to understand the impact of the detailed determinants of location selection on the shop revenue, we have created the determinants of the location selections discussing with the experts of the field. The determinants were converted into a questionnaire and were distributed among the shop owners around the region. The owners have filled the questionnaire and rated their locations from the determinants points of view. Lastly, they have indicated their GSM card sale revenues in the form.

The collected data was analyzed proposing regression analysis via IBM SPSS 24 . Given in the results of the analyses, it was observed that revenues of the shops are becoming more if they locate their shops in costly location, where the rents and other facilities are more costly than the rest of the region. In this case, the managers of the GSM operators are suggested to select those shops, which are at more costly locations, as distributer and retailer. This strategy will increase the profitability of the GSM operators significantly.

Secondly, traffic crowdedness, popularity of the location, crowdedness of the location, accessibility, and popularity of the neighbor shops were the other significant determinants which effected the shop GSM card revenues. Therefore, we suggest the managers of the GSM operators evaluate the shops from those aspects secondarily while selecting them to be retail seller shops of their GSM cards.

Lastly, GSM operator service managers are suggested not to consider the crowdedness of shop, and distance from the center determinants as important factors while selecting the retailers. It was observed that those dimensions are not significantly affecting the revenue of the shops.

\section{References}

Abdulla, N., Wrya, H., \& Durmaz, O. (2020). Green product perception in Kurdistan Region of Iraq. Black Sea Journal of Management and Marketing, 1(1), 1-15.

Ali, S. H. K., Khan, N. S., \& Yildiz, Y. (2020). Leadership effects on CSR employee, media, customer, and NGOs. Management and Eco-nomics Research Journal, 6, Article ID 961566.

Amin, N. G. A., \& Ahmed, R. J. H. (2020). Perception of women-only cafés in Kurdistan Region of Iraq. Black Sea Journal of Management and Marketing, 1(1), 29-40.

Budur, T. (2018a). Analytic hierarchy process to evaluate corporate image, trust, and switching cost of GSM operators: A case of Kurdistan Region of Iraq. International Journal of Social Sciences \& Educational Studies, 5(2), 241-250

Budur, T. (2018b). The impact of Al-Ghazali's virtues on organizational commitment and performance: A case Study at private education institutions in Kurdistan Region of Iraq. ICABEP, Erbil-Iraq, 2, p21.

Budur, T., \& Demir, A. (2019a). Leadership effects on employee perception about CSR in Kurdistan Region of Iraq. International Journal of Social Sciences \& Educational Studies, 6(1). 142-154.

Budur, T., \& Demir, A. (2019b). Leadership perceptions based on gender, experience, and education. International Journal of Social Sciences \& Educational Studies, 6(1), 142-154.

Budur, T., \& Poturak, M. (2020). Transformational leadership and its impact on customer satisfaction. Measuring mediating effects of organizational citizenship behaviors. Middle East Journal of Management.

Budur, T., \& Poturak, M. (2021). Employee performance and customer loyalty: Mediation effect of customer satisfaction. Middle East Journal of Management. 
Budur, T., Faraj, K. M., \& Karim, L. A. (2019). Benchmarking operations strategies via hybrid model: A case study of caférestaurant sector, Amazonia Investiga, 8, 842-854.

Budur, T., Rashid, C. A., \& Poturak, M. (2018). Students' perceptions on university selection, decision making process: A case study in Kurdistan Region of Iraq. International Journal of Social Sciences \& Educational Studies, 5(1), 133-144.

Canel, C., \& Khumawala, B.M. (1996). A mixed-integer programming approach for the international facilities location problem. International Journal of Operations \& Production Management, 16(4), 49-68.

Demir, A., Shawkat, S., Majeed, B.N., Budur, T. (2019). Fuzzy AHP and VIKOR to select best location for bank investment: case study in Kurdistan Region of Iraq. In Effective Investments on Capital Markets, Tarczyn'sk W, Nermend K (eds). Springer: Cham; 485-510.

Demir, A. (2019a). The impact of strategic operations management decisions on shoppers' wellbeing. Asian Academy of Management Journal, 24 (1), 25-57.

Demir, A. (2019b). A Benchmarking of service quality in telecommunication services: Case study in Kurdistan Region of Iraq. International Journal of Social Sciences \& Educational Studies, 5(3), 216-231.

Demir, A. (2020a). InterContinental Review for Diffusion Rate and Internal-External Benefits of ISO 9000 QMS. International Journal of Productivity and Quality Management. DOI: 10.1504/IJPQM.2020.10030912

Demir, A. (2020b). Impact of Internal Marketing on the Customer Perceptions in SMEs. International Journal of Services and Operations Management.

Demir, A., Maroof, L., Khan, N. U. S., \& Ali, B. J. (2020c). The role of E-service quality in shaping online meeting platforms: a case study from higher education sector. Journal of Applied Research in Higher Education. DOI: 10.1108/JARHE-082020-0253

Demir, A., \& Budur, T. (2019). Roles of leadership styles in corporate social responsibility to non-governmental organizations (NGOs). International Journal of Social Sciences \& Educational Studies, 5(4), 174-183.

Demir, A., Budur, T., \& Heshmati, A. (2020). Antecedents of trust, corporate image, and switching costs: a case in telecommunication services in the Kurdistan region of Iraq. International Journal of Mobile Communications, 19(1), 5374.

Demir, A., Budur, T., Hiwa, M., \& Heshmati, A. (2021). Links between knowledge management and organizational sustainability: Does the ISO 9001 certification have an effect? Knowledge Management Research \& Practice (TKMR), Doi: $10.1080 / 14778238.2020 .1860663$

Durmaz, O. (2017). Investigation of the motivation parameters in health care establishments. International Journal of Social Sciences \& Educational Studies, 3(4), 44.

Faeq, M. (2020). Performance evaluation criteria development process for academic staff at universities. Black Sea Journal of Management and Marketing, 1(1), 59-70.

Luthor, J. (2019). Why is business location important? Your Business, Retrieved on August 9, 2019 from https://yourbusiness.azcentral.com/business-location-important-3566.html.

Kamal, T., \& Shawkat, S. (2020). The impact of dynamic capabilities on knowledge management in Kurdistan Region of Iraq. Black Sea Journal of Management and Marketing, 1(1), 41-48.

Khan, N. U. S., \& Yildiz, Y. (2020). Impact of intangible characteristics of universities on student satisfaction. Amazonia Investiga, 9(26), 105-116.

Location Strategy - levels, system, advantages, type, company, business, system. (n.d.). Reference for business. Retrieved July 14, 2020, from https://www.referenceforbusiness.com/management/Int-Loc/Location-Strategy.html

MacCarthy, B. L., \& Atthirawong, W. (2003). Factors affecting location decisions in international operations - a Delphi study. International Journal of Operations \& Production Management, 23(7), 794-818.

Mohammed, K. S., Rashid, C. A., Salih, H. A., \& Budur, T. (2020). The role of online teaching tools on the perception of the students during the lockdown of Covid-19. International Journal of Social Sciences \& Educational Studies, 7(3), 178-190. 
Mohammed, S. S., Suleyman, C., \& Taylan, B. (2020). Burnout determinants and consequences among university lecturers. Amazonia Investiga, 9(27), 13-24.

Poturak, M., Mekić, E., Hadžiahmetović, N., \& Budur, T. (2020). Effectiveness of transformational leadership among different cultures. International Journal of Social Sciences \& Educational Studies, 7(3), 119-129.

Rashid, C. A. (2018). Efficiency of financial ratios analysis for evaluating companies' liquidity. International Journal of Social Sciences \& Educational Studies, 4(4), 110.

Sahin, O. (2014). An investigation of student satisfaction factors. Journal of Research in Business and Management, 2(6), 81.

Talley-Seijn, M. (2004). 30 years of location strategies. Plants, Sites and Parks, 31(3), 26-29.

Top, C., Abdullah, B. M. S., \& Faraj, A. H. M. (2020). Transformational Leadership Impact on Employees Performance. Eurasian Journal of Management \& Social Sciences, 1(1), 49-59.

Torlak, N. G., Demir, A., \& Budur, T. (2019). Impact of operations management strategies on customer satisfaction and behavioral intentions at café-restaurants. International Journal of Productivity and Performance Management.

Torlak, N. G., Kuzey, C., Dinc, MS., \& Budur, T. (2021). Links connecting nurses' planned behavior, burnout, job satisfaction and organizational citizenship behavior. Journal of Workplace Behavioral Health. Doi:10.1080/15555240.2020.1862675

Zaim, H., Demir, A., \& Budur, T. (2020). Ethical leadership, effectiveness and team performance: An islamic perspective. Middle East Journal of Management. 


\section{Appendix I}

Name of the Office:

Location of the Office:

Average monthly sales of the office

(Write currency only):

\section{Please rate each alternative out of 100 points}

Parking area availability (Non-Paid parking) (1 Not enough 100 Very Sufficient)

Parking Area availability (Paid parking) (1 Not enough 100 Very Sufficient)

Accessibility to the location (Ease of accessing) (1 Very Hard to Access 100 Very Easy to access)

Crowdedness of the location (1 Not Crowded 100 Very Crowded)

Crowdedness of the office (1 Not enough 100 Very Sufficient)

Traffic Jam in the neighborhood (1 means no traffic jam and 100 means high traffic jam)

Distance to the City Center (1 Very Far 100 Very Close)

Location Costs ( 1 means lower cost of rent, electricity...etc. and 100 means high costs)

Popularity of the location (1 Not popular 100 Very Popular)

Popularity of the sales office (1 Not popular 100 Very Popular) 